Pressure Politics in Industrial Societies 


\section{Also by Alan R. Ball \\ Modern Politics and Government (3rd edition) British Political Parties}




\title{
Pressure Politics in Industrial Societies
}

\author{
A comparative introduction
}

Alan R. Ball and Frances Millard

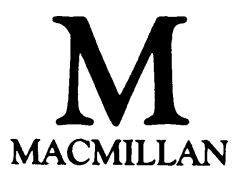


(C) Alan R. Ball and Frances Millard 1986

All rights reserved. No reproduction, copy or transmission of this publication may be made without written permission.

No paragraph of this publication may be reproduced, copied or transmitted save with written permission or in accordance with the provisions of the Copyright Act 1956 (as amended).

Any person who does any unauthorised act in relation to this publication may be liable to criminal prosecution and civil claims for damages.

First published 1986

Published by

MACMILLAN EDUCATION LTD

Houndmills, Basingstoke, Hampshire RG21 2XS

and London

Companies and representatives

throughout the world

Typesct by

Activity Limited

Salisbury, Wilts

British Library Cataloguing in Publication Data

Ball, Alan R.

Pressure politics in industrial societies: a comparative introduction.

1. Pressure groups

I. Title II. Millard, Frances

322.43 JF529

ISBN 978-0-333-34758-4

ISBN 978-1-349-18257-2 (eBook)

DOI 10.1007/978-1-349-18257-2 


\section{Contents}

$\begin{array}{ll}\text { Preface } & \text { ix }\end{array}$

1 Pressure Groups and the Distribution of Power 1

Pluralism $\quad 2$

The development of pluralism $\quad 3$

Varieties of pluralism $\quad 5$

Pluralism in socialist countries $\quad 9$

Elitist views of power $\quad 13$

Marxist approaches to power $\quad 17$

Corporatism $\quad 21$

Problems $\quad 23$

2 Problems of Pressure Group Analysis 23

The identification of pressure groups 33

Problems of cross-national comparison $\quad 37$

Classification $\quad 39$

Methods and strategies of pressure groups 41

The nature of the political system 42

The nature of the party system $\quad 44$

The political culture $\quad 46$ 
The nature and characteristics of pressure groups $\quad 47$

Power and influence $\quad 57$

3 Businessmen and Bureaucrats $\quad 57$

Introduction $\quad 57$

$\begin{array}{ll}\text { Types of groups } & 60\end{array}$

The configuration of business groups in liberal democratic states $\quad 60$

Economic bureaucracy in the planned economies $\quad 63$

Methods $\quad 65$

Business groups in liberal democracy $\quad 65$

Bureaucratic behaviour in the planned economies $\quad 72$

Strengths and weaknesses of capitalists and bureaucrats $\quad 50$

\section{Trade Unions $\quad 94$}

Types and membership $\quad 97$

Relationships with political parties 103

$\begin{array}{ll}\text { Trade union pressure group strategies } & 107\end{array}$

The power of trade unions 114

Restraints on trade unions in liberal democracies $\quad 116$

Restraints on trade unions in socialist states 121

Conclusion 124

5 Group Politics of Farming 130

Introduction $\quad 130$

Farming groups in liberal democracies $\quad 134$

Classification of farming groups $\quad 134$

The political strategies of farming groups $\quad 140$

The common market 146

The political power of farming organisations $\quad 148$

Farming interests in the USSR and Eastern Europe 153

6 Environmental Pressure Groups 165

The identification of environmental groups 166

The political resources of environmental groups $\quad 172$ 


\section{Contents vii}

$\begin{array}{ll}\text { Membership } & 172\end{array}$

$\begin{array}{ll}\text { Organisation } & 173\end{array}$

Expertise 176

$\begin{array}{ll}\text { Group strategies } & 177\end{array}$

Elections and political parties $\quad 178$

Lobbying the assembly $\quad 180$

Governments and administrative structures $\quad 181$

Judicial and administrative action and public enquiries

National campaigns and demonstrations $\quad 188$

Direct action and civil disobedience 190

The effectiveness of environmental groups 191

7 Churches and Pressure Group Politics 203

The context 204

Characteristics 207

Structure and tradition $\quad 207$

Membership $\quad 211$

The aims and methods of the churches $\quad 216$

Distinctive features of socialist states 222

Issues in religious group politics $\quad 228$

Education $\quad 228$

Abortion 232

Strengths and weaknesses of churches as pressure groups 235

8 The Military as Pressure Group 243

Introduction $\quad 243$

Givilian supremacy 244

Direct military intervention $\quad 245$

Methodological perspectives on the role of the military 247

$\begin{array}{ll}\text { The military as interest group } & 247\end{array}$

The military-industrial complex 149

Participation models $\quad 252$

Bureaucratic politics $\quad 252$

Characteristics of the military 254

Structure 254

The corporate identity of the military 256 


\section{viii Contents}

Expertise $\quad 258$

Size 261

The economic significance of the military 263

The military as decision-maker 266

Summary: military characteristics and political resources 268

Methods 269

Consultation 269

Lobbying the assembly $\quad 271$

Public relations $\quad 272$

Bureaucratic obstructionism 273

Summary: tactics and methods 275

Conclusion $\quad 275$

9 Conclusion $\quad 281$

$\begin{array}{ll}\text { Selected Bibliography } & 290\end{array}$

$\begin{array}{ll}\text { Index } & 303\end{array}$ 


\section{Preface}

Attempting a study of pressure group activity is a daunting task; to attempt a comparative study of pressure group activity presents even more difficulties. Students of politics do not agree as to what constitutes a pressure group; they offer a wide variety of schemes for the classification of pressure groups; they differ on whether pressure groups can be found in all political systems; and they inevitably offer contrasting approaches to the conceptualisation of the significance of pressure groups.

This text aims to offer a broad approach to the study of group activity by examining a range of different types of pressure groups, namely business groups and bureaucratic groups, trade unions, farmers, environmentalists, churches and the military. At the same time it attempts to place these groups' strategies and significance in the framework of a broad comparison between liberal democratic political systems and the socialist democracies of Eastern Europe. The case studies have been chosen to provide a reasonably representative cross-section of pressure group activity. Business and labour are commonly presented as the most important pressure groups, while farmers in liberal democratic states are also viewed as a particularly significant type of political grouping. The environmentalists provide a good example of what are often termed attitude or promotional groups in contrast to the former three. The churches and the military are often neglected as political actors in industrial states, though they have received considerable attention in regard to the so-called Third World countries. This alone 


\section{$x \quad$ Preface}

warrants their selection, while at the same time they extend the range of examples to a second type of promotional group and an administrative group respectively.

The comparative approach, while weakening the detail that would be possible in a more narrowly focused study, has a number of advantages. Although comparative analysis is frequent, it rarely attempts to cross the gulf between different types of political system. We have attempted to widen the comparisons and contrasts by including a number of examples which appear, at least on the surface, to be wholly different from one another. This in turn highlights the similarities within and between the two categories. Inevitably the examples here too must be selective. In the liberal democratic category we have emphasised the United States, Britain, France and West Germany. For the socialist states we have dealt mainly with the USSR and its East European allies; Albania and Yugoslavia are not absent, but references to these two states, so different in many ways from the other European socialist countries, are largely excluded.

We begin by introducing students to two important areas of pressure group analysis. Firstly, students are offered a broad outline of the four principal contrasting approaches to the distribution of political power: pluralist, elitist, corporatist and ruling class approaches are examined with particular reference to their arguments about the nature and role of pressure groups. We look at differences within each approach and we look at the ways in which each approach has been variously applied to the two types of political system, liberal democratic and socialist. With this introduction, students can then move into the realm of naming, classifying and identifying the strategies common to pressure groups as well as the restraints that operate upon them. Although we do assume some basic grasp of the political institutions of the two types of state, this remains an introductory textbook, and we make frequent reference to the wider political contexts in which groups operate. We have used self-ascribed labels, i.e. those most widely applied from within these countries themselves, to try to circumvent discussion about whether the liberal democratic states are really 'democratic' or whether 
the socialist states really are 'socialist'. However, we certainly hope to provide some fuel for such arguments.

In the case studies which follow the two introductory chapters the approach is largely empirical. By themselves, case studies cannot present a comprehensive picture of the variety of pressure group activity in any single political system. Collectively we hope they will allow the student a greater grasp of some of the broad similarities and differences that can be observed, and will encourage more specialised study of the policy processes of modern industrial states.

We have not always agreed with one another in the process of this work's genesis and development, and we do not always agree now. We hope that the inevitable compromises do not prove too patchy or too shallow. Our friend and colleague, Fergus Carr, has helped to arbitrate some of the disputes, and we thank him for his patience and his assistance. We also thank our son Adam, who proved more than tolerant in the face of extended bouts of parental neglect; he also helped enormously in dealing with the vagaries of the computer.

Alan R. Ball

Frances Millard 
To Alison, Michael, Peter and Adam 